\title{
Feasibility study and optimization of infant formula production using a mixture of camel milk and cow milk
}

\author{
Morteza RAEISI GAHROUI ${ }^{1}$, Mohammad HOJJATOLESLAMY ${ }^{1 \star}$ (D), Hossein KIANI ${ }^{1,2}$, Hooman MOLAVI ${ }^{1}$
}

\begin{abstract}
Breast milk is the best food for the baby and infant formula is an essential food for infants who are deprived of breast milk. There has been a lot of research on the optimization of infant formula that uses different milks. The composition of camel milk is close to human milk and is important in terms of nutritional properties, non-food allergy and medicinal value and therapeutic applications, and this can be an appropriate alternative to cow's milk in infant formula. In the present study, the effect of replacing cow's milk with camel's milk in infant formula was investigated. The number of treatments was determined by using the Mixture Design method and the necessary tests were performed for infant formula and physicochemical and qualitative tests including moisture, dry matter, measurement of color parameters, density, particle size, insoluble index, $\mathrm{pH}$, acidity, total sugar, fat, protein, ash, vitamin C, minerals, aflatoxin M1, wettability acceptable and scorched particles were done. The results showed that adding camel's milk to cow's milk could meet $87.3 \%$ of our expectations for the production of infant formula from camel's milk and not have an adverse effect on the physicochemical properties of the formula.
\end{abstract}

Keywords: camel milk; cow milk; infant formula; mixture design; optimization.

Practical Application: Results of present study can be used as basis for industrial use of camel milk in spray drying and infant formula. In this study important factors for dried milk powder producing using camel milk in different ratios have been investigated that can open new aspects in industrial use of camel milk.

\section{Introduction}

Milk is an essential food for children and it is clear that the best source of nutrition for babies is breast milk. The World Health Organization recommends that infants be exclusively breastfed for the first six months of life. Although it is not possible to produce the same product as breast milk, attempts have been made to imitate the nutritional characteristics of breast milk for the normal growth of infants. Infant Formula is considered as an effective alternative to breast milk and has been prepared to mimic the nutritional composition of breast milk. Formulas need to meet the factors of normal physical growth quality and adequate biological quality. However, on the one hand, due to some nutritional problems caused by cow's milk, and on the other hand, due to the better properties of camel's milk, possibility of using Camel milk instead of cow milk was tested (Martin et al., 2016).

According to FAO statistics, in 2016, the world's camels were 28.5 million people, which produced about 2.7 million liters of fresh milk. The number of camels and camel milk is expected to increase steadily over the next few years. In terms of nutrition, camel's milk is closer to human milk than other ruminants' milk (Ho et al., 2019).

Cow's milk causes hypochromia due to iron deficiency in infants, but less so in camel's milk due to its high iron content. Its lactoferrin protein is several times more than cow's milk and it has antibacterial and antiviral properties. Therefore, it has the ability to fight diseases such as cancer, Alzheimer, hepatitis $\mathrm{C}$, tuberculosis and HIV. Cow's whey protein has more betalactoglobulin and less alpha-lactalbumin, while camel's whey protein is deficient in beta-lactoglobulin, and alpha-lactalbumin is the major component. Due to the lack of beta-lactoglobulin and alpha-lactalbumin, which is similar to human milk, the use of camel milk in infant formula is recommended. Camel milk proteins include casein and whey protein. These proteins are important components of camel milk and have different functions. The amount and type of amino acids in camel's milk, except lysine, glycine, threonine and valine, are high. Short-chain fatty acids are low in camel's milk, but long-chain fatty acids are high. Camel milk is also high in linoleic acid and unsaturated fatty acids, which are important for nutrition. Camel milk has therapeutic effects on hepatitis, tuberculosis, cancer, diabetes, cirrhosis of the liver, autism, Crohn's disease, lactose intolerance and diarrhea (Zibaee et al., 2015).

Compared to milk produced by other ruminants, camel milk has great value because of its small fat globules and hypoallergenic properties due to its better digestion in the human digestive system and less allergen than cow milk (Zouari et al., 2020). The MUFA content of camel's milk (56-80/100 g of fatty acids) is higher than cow's milk (26/100 $\mathrm{g}$ of fatty acids). This fact may have beneficial effects on consumers at risk of cardiovascular 
disease. Camel milk has higher amounts of certain vitamins and minerals. It is rich in vitamins, especially vitamin $\mathrm{C}$, which is more than cow's and human milk. Camel milk is a source of vitamin A (almost twice as much as cow's milk) and it is very rich in vitamin $\mathrm{D}$ and riboflavin. In addition, this milk, due to having a mineral almost similar to human milk, can provide the most minerals needed for humans $3 \& 4$. The level of Lysozyme enzyme ( $\mathrm{N}$-acetyl- $\beta$-d-glucosaminidase), which provides antimicrobial activity, is higher in camel milk than in other ruminants. This may provide a strong innate immunity and have a higher natural resistance to disinfection (Rahmeh et al., 2019).

\section{Materials and methods}

\subsection{Sample preparation}

In this study, fresh camel milk was collected from a camel farm in Yazd province, Iran. Minerals, fat, protein, lactose and aflatoxin M1 were measured in whole camel milk (Table 1). Fresh cow's milk was also collected from cow farm in Isfahan province, Iran. Fat, protein, lactose, aflatoxin M1 in whole cow's milk were measured (Table 1).

\subsection{Pasteurizing milk}

Milk samples were pasteurized at $65^{\circ} \mathrm{C}$ for 30 minutes using a pasteurizer manufactured by Niksanat, Iran and transferred to a cold room at $4{ }^{\circ} \mathrm{C}$ for cooling (Habtegebriel et al., 2018).

\subsection{Separation of cream}

Whole milk cream (milk at $4^{\circ} \mathrm{C}$ ) was separated at $3500 \mathrm{~g}$ for 10 minutes using desktop centrifuge (2-16P, Sigma, Germany), with a capacity of $50 \mathrm{~mL}$ per cup.

\subsection{Producing infant formula}

After fattening and preparation of raw milk of cows and camels, treatments were determined based on the proposal of Design Expert (ver10) with Mixture Design method (Table 2). To prepare the emulsion, demineralized whey powder (Lactalis, France), lactose powder (Lactalis, France), vegetable oil (VFI, Austria) and other components of Infant Formula were added to treatments and mixed using a magnetic stirrer (the formula was given according to the formulation in Table 3. The mixture was heated to $50{ }^{\circ} \mathrm{C}$ by water bath and homogenized for 2 minutes using a ULTRA-TURRAX ${ }^{\circledR}$ T25 basic homogenizer)IKA-WERKE, Germany) at 13,500 rpm for 2 minutes (Phan et al., 2014). Infant formula was produced using spray drying method. In this research, a spray dryer (BUCHI b-290, Switzerland), which was equipped with a liquid nozzle with a water evaporation capacity of 1 liter per hour, was used. The atomic compressor air intake was set at $40 \mathrm{kPa}$. The inlet and outlet temperatures of the drying air were controlled at $160{ }^{\circ} \mathrm{C}$ and $70^{\circ} \mathrm{C}$, respectively. The powders were collected and placed in vacuum sealed aluminum bag (Ho et al., 2019).

\subsection{Determination of physicochemical composition}

\section{Particle size}

To distribute the particle size, the powder samples were sieved through a number of JEL 200 sieves, Engelsmann, Germany, along with rubber blocks of different mesh sizes, using a horizontal oscillation motion and divided into sections with different particles size (Denmark, 2005b).

\section{Moisture and dry matter}

Moisture content of infant formula powders was measured by AOAC method 990.20 with the help of an oven (U630, Fater Electronic Co. Iran), 1 gram of sample was dried at $105^{\circ} \mathrm{C}$ for 4 hours $\left(105 \pm 1^{\circ} \mathrm{C}\right.$ for $4 \mathrm{~h}$ ) or until a constant weight difference of $0.001 \mathrm{~g}$ was obtained (Association of Official Analytical Chemists, 1993).

\section{Protein}

Protein content was measured using the AOAC Official Method 930.29 (Association of Official Analytical Chemists, 1930a) and with a Kjeldahl digester (TR model of Gerhardt Company in Germany).

Fat

Fat content was calculated using AOAC Official Method 989.05 (Association of Official Analytical Chemists, 1992).

\section{pH measurement}

The $\mathrm{pH}$ of the samples was measured by the $\mathrm{pH}$ meter (766 Calimatic model, knick, Germany) at $20{ }^{\circ} \mathrm{C}$ (Won Seo et al., 2018).

Ash

The amount of ash using AOAC Official Method 930.30 (Association of Official Analytical Chemists (1930b) at $500{ }^{\circ} \mathrm{C}$ was measured. Ash percentage was obtained by Equation 1.

$\% \mathrm{Ash}=\frac{\mathrm{W}_{\mathrm{A}}}{\mathrm{W}} \times 100$

$\mathrm{W}_{\mathrm{A}}$ : Ash weight obtained; W: Sample weight.

Table 1. Specifications of camel and cow milk used.

\begin{tabular}{|c|c|c|c|c|c|}
\hline & Fat (\%) & Protein (\%) & Lactose $(\%)$ & Ash (\%) & Aflatoxin M1(ppt) \\
\hline Cow & 2.8 & 2.8 & 4.5 & 0.66 & $<25$ \\
\hline Camel & 2.9 & 2.6 & 4.3 & 0.71 & $<25$ \\
\hline
\end{tabular}


Table 2. Results of statistical analysis of the studied parameters and proposed equations by Mixer Design method in Design Expert software.

\begin{tabular}{|c|c|c|c|c|c|c|c|c|c|}
\hline \multirow[b]{2}{*}{ Parameter } & $\mathrm{A}$ & $\mathrm{B}$ & $\mathrm{AB}$ & $\mathrm{AB}(\mathrm{A}-\mathrm{B})$ & $\mathrm{AB}(\mathrm{A}-\mathrm{B})^{2}$ & & & & \\
\hline & Camel & Cow & Camel ${ }^{*}$ Cow & $\frac{\text { Camel }^{*} \text { Cow }}{\text { (Camel-Cow })}$ & $\frac{\text { Camel }^{\star} \text { Cow }}{(\text { Camel-Cow })^{2}}$ & F-value & R-Squared & Model & $\mathrm{S} / \mathrm{Ns}$ \\
\hline Fat & +0.29 & +0.27 & $10^{-4} \times-3.84$ & $10^{-6} \times+6.00$ & - & 47.08 & 0.97 & Cubic & $\mathrm{S}^{* *}$ \\
\hline Carbohydrate & +0.61 & +0.62 & - & - & - & 24.59 & 0.80 & Linear & $\mathrm{S}^{* *}$ \\
\hline Ash & +0.02 & +0.02 & - & - & - & 9.14 & 0.60 & Linear & $\mathrm{S}^{*}$ \\
\hline Vitamin c & +0.47 & +0.39 & $10^{-3} \times-2.47$ & - & - & 17.54 & 0.88 & Quadratic & $\mathrm{S}^{* *}$ \\
\hline Protein & +0.11 & +0.12 & - & - & - & 26.58 & 0.82 & Linear & $\mathrm{S}^{* *}$ \\
\hline Humidity & +0.018 & +0.014 & $10^{-5} \times+3.88$ & $10^{-6} \times-2.57$ & - & 12.07 & 0.90 & Cubic & $\mathrm{S}^{*}$ \\
\hline dry matter & +0.98 & +0.99 & $10^{-5} \times-3.76$ & $10^{-6} \times+2.57$ & - & 12.54 & 0.90 & Cubic & $\mathrm{S}^{*}$ \\
\hline $\mathrm{pH}$ & +0.068 & +0.067 & $10^{-5} \times+6.05$ & $10^{-7} \times-9.47$ & - & 21.05 & 0.94 & Cubic & $\mathrm{S}^{\star *}$ \\
\hline Acidity & - & - & - & - & - & - & 0.64 & Cubic & Ns \\
\hline Phosphorus & +0.49 & +0.47 & $10^{-4} \times+2.25$ & $10^{-5} \times-1.01$ & - & & 0.99 & Cubic & $\mathrm{S}^{* *}$ \\
\hline Iron & +9.46 & +0.01 & $10^{-5} \times+2.31$ & $10^{-6} \times-1.46$ & - & 11.34 & 0.90 & Cubic & $\mathrm{S}^{*}$ \\
\hline Calcium & +0.76 & +0.68 & - & - & - & 10.51 & 0.64 & Linear & $\mathrm{S}^{*}$ \\
\hline Copper & +0.67 & +0.66 & $10^{-3} \times-1.38$ & - & - & 63.40 & 0.96 & Quadratic & $\mathrm{S}^{* *}$ \\
\hline Potassium & +1.30 & +1.17 & - & - & - & 12.31 & 0.67 & Linear & $\mathrm{S}^{*}$ \\
\hline Zinc & - & - & - & - & - & - & 0.01 & Linear & Ns \\
\hline Magnesium & +0.08 & +0.10 & - & - & - & 77.12 & 0.93 & Linear & $\mathrm{S}^{* *}$ \\
\hline Sodium & +0.31 & +0.27 & $10^{-4} \times-3.65$ & - & - & 168.74 & 0.99 & Quadratic & $\mathrm{S}^{* *}$ \\
\hline $\mathrm{L}^{\star}$ & - & - & - & - & - & - & 0.58 & Cubic & Ns \\
\hline$a^{*}$ & -0.04 & -0.05 & $10^{-4} \times+1.19$ & $10^{-6} \times-1.53$ & $10^{-8} \times+4.57$ & 15.13 & 0.95 & Quartic & $S^{*}$ \\
\hline$b^{*}$ & +0.12 & +0.14 & $10^{-4} \times-5.25$ & $10^{-6} \times+9.65$ & - & 23.93 & 0.95 & Cubic & $\mathrm{S}^{* *}$ \\
\hline $\mathrm{E} \Delta$ & +0.09 & +0.09 & $10^{-5} \times-5.58$ & $10^{-7} \times-5.42$ & $10^{-8} \times-2.46$ & 17.84 & 0.96 & Quartic & $\mathrm{S}^{*}$ \\
\hline Aflatoxin & - & - & - & - & - & - & 0 & Mean & Ns \\
\hline Particle size & - & - & - & - & - & - & 0 & Mean & Ns \\
\hline Density & - & - & - & - & - & - & 0 & Mean & Ns \\
\hline Insoluble Index & - & - & - & - & - & - & 0.44 & Quadratic & Ns \\
\hline Wettability & - & - & - & - & - & - & 0 & Mean & Ns \\
\hline
\end{tabular}

$S^{*}$ : significance at $5 \%$ level; $S^{* *}$ : significance at $1 \%$ level; Ns: non-significant.

\section{Vitamin C}

Vitamin C was evaluated by titration method according to AOAC Official Method 985.33 (Association of Official Analytical Chemists, 1988a) according to Equation 2.

$$
\text { Vit c } \frac{\mathrm{mg}}{100 \mathrm{~g}}=\frac{\mathrm{V} \times \mathrm{V}_{\mathrm{m}} \times 100 \times \mathrm{F}}{\mathrm{V}_{\mathrm{s}} \times \mathrm{W}}
$$

$\mathrm{V}=$ usage of volume dichlorophenolindophenol solution; $\mathrm{V}_{\mathrm{m}}=$ volume of Sample and metaphosphoric acid solution; $\mathrm{F}=\mathrm{mg}$ of ascorbic acid equivalent to $1 \mathrm{~mL}$ of dichlorophenolindophenol solution; $\mathrm{V}_{\mathrm{s}}$ = the volume of filtered solution; $\mathrm{W}=$ the initial weight of the powder sample.

\section{Acidity}

The titratable acidity was expressed as lactic acid and by titration a certain amount of milk reconstituted with $0.1 \mathrm{~N}$ $\mathrm{NaOH}$ using phenolphthalein as an indicator was determined (Denmark, 2006c).

\section{Phosphorus}

Phosphorous content of samples evaluated by AOAC Official method (986.24) at $820 \mathrm{~nm}$ (Association of Official Analytical Chemists, 1988c).

\section{Insoluble index}

Insoluble index of treatment tested by ISO 8156:2005 (IDF 129:2005) method (International Organization for Standardization, 2005).

\section{Scorched particles}

The amount of particles scorched in the powder using GEA Niro Method No. A 4 a (Denmark, 2006a), and then a comparison with the ADMI chart (Figure 1) were determined.

\section{Bulk density}

To measure the bulk density, a Stampfvolumeter (Engelsmann, Germany) was used. The powder sample was transferred to a measuring cylinder and 100 beats were applied to it and calculated according to Equation 3 in $\mathrm{kg} / \mathrm{m}^{3}$ (Denmark, 2006b).

$\rho_{100}=\mathrm{m} / \mathrm{v}_{100}$

\section{Carbohydrate}

According to AOAC 986.25 (Association of Official Analytical Chemists, 1985), to determine the amount of total Carbohydrate, the following Equation 4 was used: 
Table 3. Optimizing the mixing of cow's milk with camel's milk to obtain the infant formula according to the infant formula.

\begin{tabular}{|c|c|c|c|c|c|c|}
\hline \multirow[t]{2}{*}{ Parameter } & \multirow{2}{*}{ unit } & \multicolumn{2}{|c|}{$\begin{array}{l}\text { Standard acceptance } \\
\text { range }\end{array}$} & \multirow{2}{*}{$\begin{array}{c}\text { The optimal } \\
\text { value obtained } \\
\text { by the software }\end{array}$} & \multirow[t]{2}{*}{ Experimental value } & \multirow[t]{2}{*}{ Reference } \\
\hline & & Min & $\operatorname{Max}$ & & & \\
\hline Fat & $\%$ & 22.53 & 30.72 & 26.40 & $26.10 \pm 1.04$ & $\begin{array}{l}\text { Codex Alimentarius (Food and } \\
\text { Agriculture Organization, 2007) }\end{array}$ \\
\hline carbohydrate & $\%$ & 46.08 & 71.68 & 61.69 & $60.71 \pm 2.14$ & Codex Alimentarius \\
\hline Ash & $\%$ & 0 & 3 & 2.12 & $2.09 \pm 0.11$ & Commission on Dry Milk (Iran, 2009) \\
\hline Vitamin c & $\mathrm{mg} / 100 \mathrm{kcal}$ & 10 & 50 & 36.50 & $36.25 \pm 0.82$ & Commission on Dry Milk (Iran, 2009) \\
\hline Protein & $\%$ & 9.22 & 15.36 & 11.35 & $11.22 \pm 0.27$ & $\begin{array}{l}\text { Codex Alimentarius (Food and } \\
\text { Agriculture Organization, 2007) }\end{array}$ \\
\hline Humidity & $\%$ & 0 & 3 & 1.74 & $1.72 \pm 0.05$ & $\begin{array}{c}\text { Codex Standard (Food and Agriculture } \\
\text { Organization, 1994) }\end{array}$ \\
\hline dry matter & $\%$ & 97 & 100 & 98.26 & $98.30 \pm 0.05$ & $\begin{array}{c}\text { Codex Standard (Food and Agriculture } \\
\text { Organization, 1994) }\end{array}$ \\
\hline Acidity & $\begin{array}{l}\mathrm{g} / 100 \mathrm{~mL} \\
\text { Lactic acid }\end{array}$ & 0 & 0.14 & 0.04 & $0.04 \pm 0.01$ & $\begin{array}{c}\text { Codex Standard (Food and Agriculture } \\
\text { Organization, 1994) }\end{array}$ \\
\hline Phosphorus & $\mathrm{mg} / 100 \mathrm{kcal}$ & 25 & 100 & 48.68 & $48.50 \pm 0.32$ & $\begin{array}{l}\text { Codex Alimentariu s (Food and } \\
\text { Agriculture Organization, 2007) }\end{array}$ \\
\hline Iron & $\mathrm{mg} / 100 \mathrm{kcal}$ & 0.5 & 2 & 1.20 & $1.20 \pm 0.03$ & $\begin{array}{c}\text { Codex Standard (Food and Agriculture } \\
\text { Organization, 1994) }\end{array}$ \\
\hline Calcium & $\mathrm{mg} / 100 \mathrm{kcal}$ & 50 & 140 & 70.84 & $70.80 \pm 0.13$ & $\begin{array}{l}\text { Codex Alimentarius (Food and } \\
\text { Agriculture Organization, 2007) }\end{array}$ \\
\hline Copper & $\mu \mathrm{g} / 100 \mathrm{kcal}$ & 35 & 120 & 62.98 & $61.56 \pm 0.50$ & $\begin{array}{l}\text { Codex Alimentarius (Food and } \\
\text { Agriculture Organization, 2007) }\end{array}$ \\
\hline potassium & $\mathrm{mg} / 100 \mathrm{kcal}$ & 60 & 180 & 122.21 & $119.11 \pm 3.88$ & $\begin{array}{l}\text { Codex Alimentarius (Food and } \\
\text { Agriculture Organization, 2007) }\end{array}$ \\
\hline Zinc & $\mathrm{mg} / 100 \mathrm{kcal}$ & 0.5 & 1.5 & 0.65 & $0.64 \pm 0.21$ & $\begin{array}{l}\text { Codex Alimentarius (Food and } \\
\text { Agriculture Organization, 2007) }\end{array}$ \\
\hline Magnesium & $\mathrm{mg} / 100 \mathrm{kcal}$ & 5 & 15 & 9.08 & $9.03 \pm 0.21$ & $\begin{array}{l}\text { Codex Alimentarius (Food and } \\
\text { Agriculture Organization, 2007) }\end{array}$ \\
\hline Sodium & $\mathrm{mg} / 100 \mathrm{kcal}$ & 20 & 60 & 27.50 & $27.43 \pm 0.11$ & $\begin{array}{l}\text { Codex Alimentarius (Food and } \\
\text { Agriculture Organization, 2007) }\end{array}$ \\
\hline $\mathrm{L}^{*}$ & - & - & - & 92.95 & $92.88 \pm 0.10$ & - \\
\hline$a^{*}$ & - & - & - & -3.94 & $-3.99 \pm 0.08$ & - \\
\hline$b^{*}$ & - & - & - & 11.59 & $12 \pm 0.08$ & - \\
\hline $\mathrm{E} \Delta$ & - & - & - & 8.87 & $8.93 \pm 0.11$ & - \\
\hline Aflatoxin & Ppt & 0 & 25 & 10.17 & $10.09 \pm 0.05$ & $\begin{array}{l}\text { Food \& Feed Mycotoxins (Food \& Feed, } \\
\text { 2003) }\end{array}$ \\
\hline Particle size & $\mu \mathrm{m}$ & - & - & Ns & - & - \\
\hline Density & $\mathrm{kg} / \mathrm{m} 3$ & - & - & 445.63 & $445.42 \pm 0.31$ & - \\
\hline Insoluble Index & Ml & - & - & 0.10 & $0.10 \pm 00$ & - \\
\hline
\end{tabular}

Carbohydrate $=$ total solids $-($ proteins + fat + ash $)$

\section{Aflatoxin M1}

Aflatoxin M1 was analyzed by liquid chromatography (HPLC). To measure aflatoxin M1, C18 column and fluorescent detector at $30{ }^{\circ} \mathrm{C}$ with emission of $405 \mathrm{~nm}$ with reverse phase chromatography of Hitachi model made in Japan were used. The injection volume of the solvents used was $50 \mathrm{~mL}$ of $40 \%$ sodium and methanol buffer. All chromatographic data were reprocessed and analyzed in ELSI software (Wang et al., 2012).

\section{Metals measurement}

Minerals including iron, calcium, magnesium, potassium, sodium, zinc and copper, were determined using AOAC
985.35 method (Association of Official Analytical Chemists, 1988b).

\section{Colorimetric test}

Colorflex EZ colorimeter (Hunterlab, USA) was used to determine the color of powder samples. The factors $L^{\star}$ (dark and light), $\mathrm{a}^{*}$ (red and green) and $\mathrm{b}^{*}$ (yellow and blue) were measured. All measurements were performed in triplicate for each sample (Won Seo et al., 2018).

\section{Wettability}

Certain amount of powder was poured into water at a certain temperature, according to the GEA Niro method No. A 5 a used for milk powder and other dry dairy products. If the 
powder does not get wet after 5 minutes, the analysis stops and the result is $>300$ seconds (Denmark, 2005a).

\section{Sensory analysis}

Hedonic (descriptive) test is a common method in sensory analysis that based on instantaneous perception and feeling of panelists. In present study 5 points hedonic test has been applied and sensory properties of powdered dried milk treatments have been evaluated and their overall acceptance of treatments was reported (Silva et al., 2018).

\section{Results and discussion}

The results of chemical tests of camel and cow milk can be seen in Table 1. As shown in Table 1, the amount of aflatoxin M1 in both milk samples is within the allowable range.

According to Figure 2a, due to the lower amount of primary protein in camel's milk (Table 1), the amount of milk powder produced with this milk was less than the amount of protein produced from cow's milk. These results were consistent with a study by Soliman (2005) who found that camel milk protein was lower than that of cow, buffalo, and goats.

The lower amount of primary total carbohydrates (especially lactose) in camel's milk compared to cow's milk (Table 1), has caused the amount of this factor to decrease in the milk powder produced by increasing the amount of camel's milk (according to Figure $2 \mathrm{~b}$ ). These results were inaccorddance with the study by Soliman (2005).

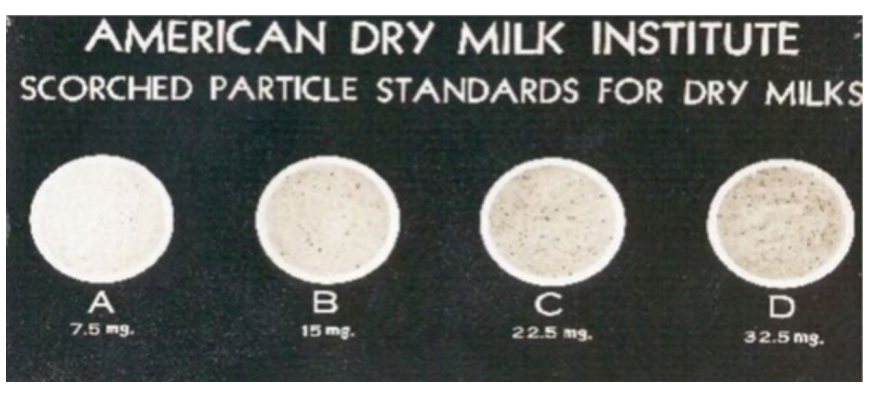

Figure 1. ADMI chart Scorched Particles Standards for Dry Milk.
As indicated in Figure 2c, with increasing the level of camel milk in the produced milk powder, its fat content has increased, which can be interpreted due to the higher initial amount of camel milk fat (Table 1). The same results have been achieved in study of Ibrahim et al. (2018) who believed that the amount of fat in camel milk is higher than cow and goat milk.

The amount of ash has increased with increasing the amount of camel milk (Figure 2d), which can be interpreted due to the high initial amount in camel milk.

These results were in accordance with Soliman (2005), reported that camel's milk ash contained more milk than cow milk and less than buffalo and goat milk.

The highest moisture content of milk powder was related to milk powder containing $100 \%$ camel milk and the lowest was related to milk powder containing 100\% cow's milk (Figure 2f). Conversely, the highest amount of dry matter was related to milk powder containing $100 \%$ cow's milk and the lowest was related to Powdered milk contains $100 \%$ camel milk (Figure 2e), which can be attributed to the structure of protein, carbohydrates and other substances in milk, but the results of the image can help to clarify the reason for this case. Compared with the study by Habtegebriel et al. (2018), they stated that humidity is related to the interaction between all liquid spraying operations and the outlet temperature in general.

Although the $\mathrm{pH}$ of milk powder produced in all treatments was in the desired range (Figure $2 \mathrm{~g}$ ). Powdered milk produced from cow's milk and camel's milk are not significantly different in terms of acidity. These results were consistent with a study by Eshraga et al. (2011) who reported that camel milk had higher humidity and $\mathrm{pH}$ than cow milk.

Milk is not a good source of vitamin C, but the results show that camel's milk can increase the amount of vitamin $\mathrm{C}$ in powdered milk by up to $10 \%$ (Figure $2 \mathrm{i}$ ). As shown in Table 4, the amount of vitamin $\mathrm{C}$ added is more than the amount of milk powder produced. These results were consistent with the study of. Mohamed \& Al-Rasheedi (2013) agreed that the level of vitamin $\mathrm{C}$ in camel milk is higher than that in cow's milk.

Table 4. Nutrients added to formula.

\begin{tabular}{|c|c|c|c|c|c|c|}
\hline Parameter & Unit & $\begin{array}{l}\text { demineralized } \\
\text { whey powder }\end{array}$ & Lactose & Oil & Premix $^{*}$ Vitamin & Premix $^{*}$ Minerals \\
\hline Protein & $\%$ & 5.44 & - & - & - & - \\
\hline Fat & $\%$ & - & - & 27 & - & - \\
\hline carbohydrate & $\%$ & 37.23 & 12.07 & - & - & - \\
\hline Vitamin c & $\mathrm{mg} / 100 \mathrm{kcal}$ & - & - & - & 57.29 & - \\
\hline Iron & $\mathrm{mg} / 100 \mathrm{kcal}$ & - & - & - & - & 0.8 \\
\hline Sodium & $\mathrm{mg} / 100 \mathrm{kcal}$ & 7.70 & - & - & 4.49 & 1.34 \\
\hline Potassium & $\mathrm{mg} / 100 \mathrm{kcal}$ & 17.11 & - & - & - & 41.03 \\
\hline Phosphorus & $\mathrm{mg} / 100 \mathrm{kcal}$ & 10.28 & - & - & - & 1.04 \\
\hline Copper & $\mu \mathrm{g} / 100 \mathrm{kcal}$ & - & - & - & - & 61.88 \\
\hline Zinc & $\mathrm{mg} / 100 \mathrm{kcal}$ & - & - & - & - & 0.50 \\
\hline Magnesium & $\mathrm{mg} / 100 \mathrm{kcal}$ & 2.14 & - & - & - & 2.44 \\
\hline Calcium & $\mathrm{mg} / 100 \mathrm{kcal}$ & 17.13 & - & - & - & 9.58 \\
\hline
\end{tabular}

*Premix: Additional constant mineral and vitamins that have been added to dried milk powder. 

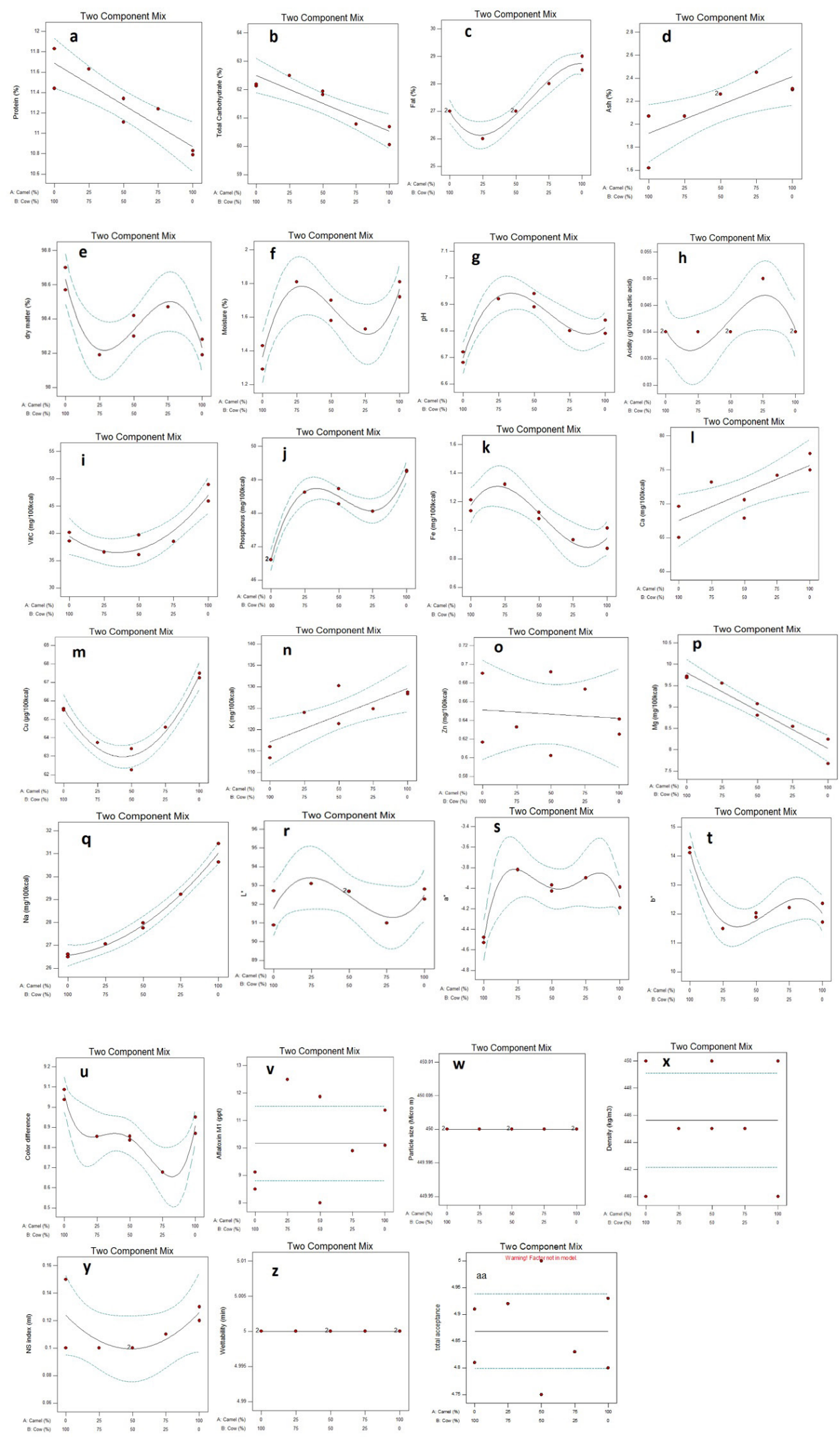

Figure 2. Investigation of the effect of mixing camel milk and cow's milk on the physicochemical properties of milk powder produced. (a) effect on protein; (b) effect on total carbohydrates; (c) effect on fat; (d) effect on ash; (e) effect on dry matter; (f) effect on moisture; (g) effect on pH; (h) effect on acidity; (i) effect on vitamin $\mathrm{C}$; ( $\mathrm{j}$ ) effect on phosphorus; (k) effect on iron; (l) effect on calcium; (m) effect on copper; (n) effect on potassium; (o) effect on zinc; (p) effect on magnesium; (q) effect on sodium; (r) effect on $\mathrm{L}^{*}$; (s) effect on $\mathrm{a}^{*}$; ( $\mathrm{t}$ ) effect on $\mathrm{b}^{*}$; (u) effect on $\Delta \mathrm{E}$; (v) effect on Aflatoxin M1; (w) effect on particle size; (x) effect on density; (y) effect on index Insolubility; (z) effect on Wettability. 
One of the important factors in milk powder production, especially if it is used as infant milk powder, is the amount of phosphorus in it, camel milk has the highest amount of phosphorus in milk powder contained (Figure 2j). These results were consistent with the study by Nikkhah (2011) who believed that camel milk phosphorus was higher than cow milk.

According to Figure $2 k$, the amount of iron is in the normal range, its amount in the milk powder produced has decreased by about $20 \%$ with the increase in the amount of camel milk. These results were consistent with the study by Chen et al. (2020) who stated that the amount of iron in camel milk was less than cow's milk and more than goat's and buffalo's milk. The amount of calcium in the milk powder produced, as shown in Figure 2l, increased with the amount of camel milk. These results were consistent with the study by Chen et al. (2020). As showed in Figure $2 \mathrm{~m}$, the amount of copper in the milk powder produced has not changed significantly compared to the changes in cow's milk and camel's milk. Therefore, increasing the ratio of camel milk to milk powder will not affect the amount of copper content in it. Chen et al. (2020) also declared that camel milk had higher copper content than cow.

The amount of potassium in the produced milk powder increased with the amount of camel milk, which can be seen in Figure 2n. The same results were reported by Soliman (2005).

In addition, as illustrated in Figure 2q, the amount of sodium in the produced dry milk has also increased with higher amounts of camel milk. These results were in accordance with Chen et al. (2020) that the amount of sodium in cow and buffalo milk is higher than camel milk.

The results of adding camel milk to milk powder showed that the amount of zinc in the milk powder produced did not change significantly, so the addition of camel milk will not have a detrimental effect on the amount of this mineral in the milk powder produced (Figure 2o). These results were comparable with the study of Chen et al. (2020) and showed that the amount of zinc in camel milk was slightly higher than the amount in cow, buffalo and goat milk. Adding camel's milk to cow's milk in formula can reduce the amount of magnesium from about 9.7 to 7.7 , (according to Figure 2o). Therefore, by reducing the amount of this element, its amount should be compensated with additives that are added to powdered milk. Chen et al. (2020) also reported the same results for camel milk.

The value of brightness index $\left(\mathrm{L}^{\star}\right)$ did not change significantly with changes in camel milk volume (Figure 2r). Also, with increasing the amount of camel milk, the $\mathrm{a}^{*}$ increased slightly, which was not significant (Figure 2s) and index $b^{\star}$ decreased with increasing camel milk (Figure 2t). As shown in the Figure $2 \mathrm{u}$, the color difference $(\Delta \mathrm{E})$ did not show a significant difference compared to the control ( $100 \%$ cow's milk), which is a promising result in the using of camel's milk in formula without having changes in its appearance characteristics. These results were consistent with a study by Sulieman et al. (2014). That reported the color of the milk powder resulting from drying with camel milk spray dryer was yellow and lighter.

The amount of aflatoxin M1 in the formula is a function of aflatoxin M1 content in raw materials, which is a function of the way the animal is fed and other animal health conditions, so it cannot be called a constant factor. Due to the fact that the amount of aflatoxin M1 in the initial milk of cows and camels was not significantly different, so in the dry milk produced as shown in the Figure $2 v$, there is no significant difference. These results were compared with the study of Yousof \& El Zubeir (2020) and the results showed that the aflatoxin content in traditional feeding is lower that camels that kept under industrial livestock.

Particle size is an important factor in dried milk production. As can be seen in the Figure 2w, the composition of camel milk and cow milk has no significant difference in the particle size of the milk powder produced, which can be a positive phenomenon. The results were compared with the study of Sharma et al. (2012) and they also stated that the particle size of milk powder is related to its appearance, regeneration properties and flow characteristics, and this is influenced by the main characteristics of milk, processing conditions and type of equipment used in the drying process.

Scorched particles content in the produced milk powder is affected by the process conditions. The results showed that the amount of these particles in different treatments were not significantly different and according to Figure 1, all treatments had disk $\mathrm{A}$.

As indicated in Figure 2x, by increasing the ratio of camel or cow milk, no significant change in volumetric density has occurred. Habtegebriel et al. (2018), showed that camel milk powders were denser than cow's milk powders in similar conditions and that these results could provide insight into spray dryer design leading to physical and chemical properties of milk powder.

The amount of insoluble solids is an important and determining factor in determining the application and quality of milk powder produced physically. As shown in the Figure 2y, changes in cow and camel milk had not any significant effect on the presence of insoluble particles in the produced milk powder, which increases our hopes for using camel milk. These results were consistent with the study of Sulieman et al. (2014).

Wetting speed is another important factor, as can be seen in the Figure $2 z$, increasing the amount of camel milk in the milk powder mixture produced has no significant effect on the amount of moisture absorption. A study by Drapala et al. (2017) showed that differences in wettability between powders could be related to differences in the physical state of the protein.

As indicated in Figure 2aa, cow milk substitution by camel milk had no significant effect on sensorial acceptance of powdered dried milk that led us to produce dried milk using camel milk without any harmful effect on product.

For optimizing the results desired ranges were selected according to Table 3 . The results showed that the formulation containing $62.24 \%$ cow's milk and $37.76 \%$ camel's milk, could meet $87.30 \%$ of our expectations in adapting the physicochemical properties of the resulting milk powder to the desired properties for infant formula. To ensure the reproducibility of the optimal formulation, an optimal milk powder sample was produced in three replications. As shown in Table 3, the experimental result 
obtained did not differ significantly from the results obtained by the software.

Before the production of infant formula, fixed amounts of minerals and other nutrients were added to the milk. These values are given in Table 4, and since the amounts of these additives were constant in all treatments, changes in each can be made. One of the factors was only the difference in their amount in cow's or camel's milk and the proportion of mixed milk.

\section{Conclusion}

According to the results of the present study, combination of cow and camel milk can meet $87.3 \%$ of our expectations regarding the physicochemical properties of infant formula. Due to the relatively high production of camel milk in the Middle East and North Africa and the good benefits of camel milk, this substance can be used as a substitute for cow's milk in infant formula. Due to the fact that some formulas are added to infant formula, the differences between camel milk and cow's milk can be adjusted by using these additives. To confirm the prospect of producing infant formula from camel's milk and to support its production on an industrial scale, further research in this regard certainly requires nutritional, clinical and medical studies that these studies in the above fields can be done in vivo digestion.

\section{References}

Association of Official Analytical Chemists - AOAC. (1930a). AOAC official method 930.29: protein in dried milk. Washington: AOAC.

Association of Official Analytical Chemists - AOAC. (1930b). AOAC official method 930.30: ash of dried milk. Washington: AOAC.

Association of Official Analytical Chemists - AOAC. (1985). AOAC official method 986.25: proximate analysis of milk-based infant formula. Washington: AOAC.

Association of Official Analytical Chemists - AOAC. (1988a). AOAC official method 985.33: vitamin C (reduced ascorbic acid), in readyto-feed milk-based infant formula 2, 6-dichloroindophenol titrimetric method. Washington: AOAC.

Association of Official Analytical Chemists - AOAC. (1988b). AOAC official method 985.35: minerals in infant formula, enteral products, and pet foods, atomic absorption spectrophotometric method. Washington: AOAC.

Association of Official Analytical Chemists - AOAC. (1988c). AOAC official method 986.24: phosphorus in infant formula and enteral products. USA: AOAC.

Association of Official Analytical Chemists - AOAC. (1992). AOAC official method 989.05: fat in milk. Washington: AOAC.

Association of Official Analytical Chemists - AOAC. (1993). AOAC official method 990.20: solids (total) in milk, by direct forced air oven drying. USA: AOAC.

Chen, L., Li, X., Li, Z., \& Deng, L. (2020). Analysis of 17 elements in cow, goat, buffalo, yak, and camel milk by inductively coupled plasma mass spectrometry (ICP-MS). Journal of RSC Advances, 10(12), 6736-6742. http://dx.doi.org/10.1039/D0RA00390E.

Denmark. (2005a). GEA Niro Method - GEA Niro. Wettability. No. A 5 a. Denmark: GEA Niro.

Denmark. (2005b). GEA Niro Method-GEA Niro. Particle size distribution by sieving. No. A 8 a. Denmark: GEA Niro.
Denmark, GEA Niro Method - GEA Niro. (2006a). Scorched particles. No. A 4 a. Denmark: GEA Niro.

Denmark, GEA Niro Method - GEA Niro. (2006b). Powder bulk density. No. A 2 a. Denmark: GEA Niro.

Denmark, GEA Niro Method - GEA Niro. (2006c). Titratable Acidity. No. A 19 a. Denmark: GEA Niro.

Drapala, K. P., Auty, M. A., Mulvihill, D. M., \& O’Mahony, J. A. (2017). Influence of emulsifier type on the spray-drying properties of model infant formula emulsions. Journal of Food Hydrocolloids, 69, 56-66. http://dx.doi.org/10.1016/j.foodhyd.2016.12.024.

Eshraga, A. E., Abu Elgasim, A. Y., Efadil, E. B., \& Isam, A. M. A. (2011). Physicochemical, microbiological and sensory characteristics of yoghurt produced from camel milk during storage. Electronic Journal of Environmental. Agricultural and Food Chemistry, 10(6), 2305-2313.

Food \& Feed. (2003). Worldwide regulations for mycotoxins in food and feed - Food \& Feed. Tolerated level, Amendment No.1. USA: Food \& Feed.

Food and Agriculture Organization - FAO, Codex Alimentarius Codex. (2007). Standard for infant formula and formulas for special medical purposes intended for infants. USA: Codex.

Food and Agriculture Organization - FAO, Codex Standard - Codex. (1994). Standard for infant formula (Vol. 4). USA: Codex.

Habtegebriel, H., Edward, D., Wawire, M., Sila, D., \& Seifu, E. (2018). Effect of operating parameters on the surface and physico-chemical properties of spray-dried camel milk powders. Journal of Food and Bioproducts Processing, 112, 137-149. http://dx.doi.org/10.1016/j. fbp.2018.09.010.

Ho, T. M., Chan, S., Yago, A. J. E., Shravya, R., Bhandari, B. R., \& Bansal, N. (2019). Changes in physicochemical properties of spray-dried camel milk powder over accelerated storage. Journal of Food Chemistry, 295, 224-233. http://dx.doi.org/10.1016/j.foodchem.2019.05.122. PMid:31174753.

Ibrahim, S. I. O., Awadelkareem, A. M., Ashraf, S. A., \& Sabahelkhier, M. K. (2018). Comparative studies on the physicochemical and microbiological characteristics of different animal milk collected from the farms of Khartoum State, Sudan. Journal of Nutritional Communication, 11(3), 387-392. http://dx.doi.org/10.21786/bbrc/11.3/6.

International Organization for Standardization - ISO. (2005). Dried milk and dried milk products: determination of insolubility index ISO 8156: 2005 [IDF 129:2005]. Geneva: ISO.

Iran, Scientific Advisory Commission. (2009). Dry milk and baby food Ministry of Health, treatment and medical education of the Islamic Republic of Iran. Iran.

Martin, C. R., Ling, P. R., \& Blackburn, G. L. (2016). Review of infant feeding: key features of breast milk and infant formula. Journal of Nutrients, 8(5), 279. http://dx.doi.org/10.3390/nu8050279. PMid:27187450.

Mohamed, H. E., \& Al-Rasheedi, A. (2013). Factors affecting vitamin C contents of camel milk. Journal of Camel Practice and Research, 20(1), 45-46.

Nikkhah, A. (2011). Science of camel and yak milks: human nutrition and health perspectives. Journal of Food and Nutrition Sciences, 2(6), 667-673. http://dx.doi.org/10.4236/fns.2011.26092.

Phan, T. T. Q., Le, T. T., Van der Meeren, P., \& Dewettinck, K. (2014). Comparison of emulsifying properties of milk fat globule membrane materials isolated from different dairy by-products. Journal of Dairy Science, 97(8), 4799-4810. http://dx.doi.org/10.3168/jds.2014-8030. PMid:24913653.

Rahmeh, R., Alomirah, H., Abrar, A., \& Sidhu, J. (2019). Composition and properties of camel milk, properties of camel milk. In K. H. 
Javid (Ed.), Milk production, processing and marketing (Chap. 3, p. 43). London: Intechopen. https://doi.org/10.5772/intechopen.82592.

Sharma, A., Jana, A. H., \& Chavan, R. S. (2012). Functionality of milk powders and milk-based powders for end use applications a review. Comprehensive Reviews in Food Science and Food Safety, 11(5), 518528. http://dx.doi.org/10.1111/j.1541-4337.2012.00199.x.

Silva, H. L. A., Balthazar, C. F., Silva, R., Vieira, A. H., Costa, R. G. B., Esmerino, E. A., Freitas, M. Q., \& Cruz, A. G. (2018). Sodium reduction and flavor enhancer addition in probiotic prato cheese: contributions of quantitative descriptive analysis and temporal dominance of sensations for sensory profiling. Journal of Dairy Science, 101(10), 8837-8846. http://dx.doi.org/10.3168/jds.201814819. PMid:30077456.

Soliman, G. Z. (2005). Comparison of chemical and mineral content of milk from human, cow, buffalo, camel and goat in Egypt. The Egyptian Journal of Hospital Medicine, 21, 116-130. http://dx.doi. org/10.12816/EJHM.2005.18054.

Sulieman, A. M. E., Elamin, O. M., Elkhalifa, E. A., \& Laleye, L. (2014). Comparison of physicochemical properties of spray-dried camel's milk and cow's milk powder. International Journal of Food Science and Nutrition Engineering, 4(1), 15-19.

Wang, Y., Liu, X., Xiao, C., Wang, Z., Wang, J., Xiao, H., Cui, L., Xiang, Q., \& Yue, T. (2012). HPLC determination of aflatoxin M1 in liquid milk and milk powder using solid phase extraction on OASIS HLB. Journal of Food Control, 28(1), 131-134. http://dx.doi.org/10.1016/j. foodcont.2012.04.037.

Won Seo, C., Hong, S., Kook Shin, Y., \& Ho Kang, S. (2018). Physicochemical properties of liquid infant formula stored at different temperatures. Han-gug Chugsan Sigpum Hag-hoeji, 38(5), 995-1007. http://dx.doi. org/10.5851/kosfa.2018.e31. PMid:30479506.

Yousof, S. S. M., \& El Zubeir, I. E. M. (2020). Chemical composition and detection of Aflatoxin M1 in camels and cow's milk in Sudan. Journal of Food Additives \& Contaminants: Part B, 13(4), 298-304. http://dx.doi.org/10.1080/19393210.2020.179 6826. PMid:32723025.

Zibaee, S., Hosseini, S. M., Yousefi, M., Taghipour, A., Kiani, M. A., \& Noras, M. R. (2015). Nutritional and therapeutic characteristics of camel milk in children: a systematic review. Journal of Electronic Physician, 7(7), 1523-1528. http://dx.doi.org/10.19082/1523. PMid:26767108.

Zouari, A., Mtibaa, I., Triki, M., Jridi, M., Zidi, D., Attia, H., \& Ayadi, M. A. (2020). Effect of spray-drying parameters on the solubility and the bulk density of camel milk powder: a response surface methodology approach. International Journal of Dairy Technology, 73(3), 616-624. http://dx.doi.org/10.1111/1471-0307.12690. 